\title{
Perbandingan Pediatric Early Warning Score dan Nursing Early Warning Scoring System dalam Mengidentifikasi Deteriorasi Klinis Pasien Anak di Rumah Sakit Cipto Mangunkusumo
}

Rismala Dewi, Iqbal Zein Assyidiqie, Bambang Supriyatno

Departemen Ilmu Kesehatan Anak Fakultas Kedokteran Universitas Indonesia/ Rumah Sakit Dr. Cipto Mangunkusumo, Jakarta

Latar belakang. Berbagai macam metode dapat digunakan untuk menilai deteriorasi klinis pasien anak yang masuk di rumah sakit. Skor nursing early warning scoring system (NEWSS) merupakan skor penilaianyang dimodifikasi dari penilaian dewasa, sedangkan pediatric early warning score (PEWS) dikembangkan khusus untuk menilai pasien anak. Penggunaan PEWS untuk mengevaluasi derajat perburukan klinis pasien anak beberapa jam sebelum pasien jatuh pada kondisi kritis. Hingga saat ini, penelitian dan penggunaan skor PEWS masih belum terlalu banyak di Indonesia.

Tujuan. Membandingkan skor PEWS dan NEWSS dalam mengidentifikasi deteriorasi klinis pada pasien anak di rumah sakit. Metode. Penelitian dilakukan dengan desain uji potong lintang pada pasien anak yang masuk ke instalasi gawat darurat RSCM sejak bulan November 2019-Januari 2020. Pengambilan subjek secara consecutive sampling dengan kriteria inklusi usia anak 0-18 tahun dan skor NEWSS .

Hasil. Diperoleh 81 subjek yang memenuhi kriteria. Sebagian besar dari subjek berjenis kelamin laki (58\%), rentang usia toddlers (1-3 tahun) (27\%), dengan kasus infeksi sebagai diagnosis pasien terbanyak $(53,1 \%)$. Sebagian besar pasien juga datang akibat masalah respirasi (31\%). Didapatkan skor PEWS berhubungan erat dengan kejadian deteriorasi klinis pasien anak. Seluruh pasien dengan skor PEWS $\geq 7$ mengalami perburukan klinis. Hasil penelitian ini juga menunjukkan bahwa sensitivitas PEWS lebih baik dibandingkan dengan NEWSS (0,80; $95 \%$ CI 0,66-0,90 vs 0,58; $95 \%$ CI 0,44-0,72) dan kedua sistem skor memiliki spesifisitas yang sama baiknya $(0,9395 \%$ CI $0,77-0,99$ vs 0,96 ; $95 \%$ CI $0,82-0,99)$.

Kesimpulan. Kemampuan PEWS lebih baik untuk mendeteksi deteriorasi klinis pada pasien anak bila dibandingkan dengan NEWSS. Sari Pediatri 2020;21(6):333-8

Kata kunci: PEWS, deteriorasi klinis, anak

\section{Comparison between Pediatric Early Warning Score and Nursing Early Warning Scoring System in Identifying Clinical Deterioration in Children at Cipto Mangunkusumo Hospital}

Rismala Dewi, Iqbal Zein Assyidiqie, Bambang Supriyatno

Background. Different methods can be used to identify the degree of clinical deterioration and to prevent death in paediatric patients. The NEWSS is a modified adult scoring system, which can be used to evaluate clinical deterioration in children, while the PEWS was developed specifically to assess deteriorated pediatric patients in the hospital. The PEWS is applied to evaluate the degree of clinical deterioration several hours before the patient falls into a critical condition. Until now, the use and research of PEWS has not been found in Indonesia.

Objective. This study aims to compare PEWS and NEWSS in identifying the clinical deterioration of hospitalized pediatric patients. Methods. This was a cross-section study, conducted in the emergency department of Cipto Mangunkusumo Hospital (CMH) from November 2019 to January 2020. Consecutive sampling method was used. Inclusion criteria were children age 0-18 years old and has NEWSS

Results. There were 81 subjects who fulfilled the criteria. Most of the subjects were boys (58\%) and toddlers (1-3 years old) (27\%) with infection as the most common diagnosis $(53,1 \%)$. Most subjects had respiratory issues $(31 \%)$ when they were admitted. Statistically, PEWS was more sensitive compared to NEWSS $(0,80$; $95 \%$ CI 0,66-0,90 vs 0,58; 95\% CI 0,44-0,72) and both methods were equally specific to identify clinical deterioration in pediatric patients $(0,9395 \%$ CI $0,77-0,99$ vs 0,96 ; $95 \%$ CI $0,82-0,99)$.

Conclusion. PEWS was more superior in identifying the degree of clinical deterioration in pediatric patients who were treated in the hospital. Sari Pediatri 2020;21(6):333-8

Keyword: PEWS, clinical deterioration, pediatric

Alamat korespondensi: Rismala Dewi. Departemen Ilmu Kesehatan anak Fakultas Kedokteran Universitas Indonesia RSUPN Dr. Cipto Mangunkusumo, Jakarta. Jalan Salemba no. 6, Jakarta. Email: dewijuli22 @gmail.com 
S etiap pasien anak memiliki risiko untuk mengalami penurunan kondisi klinis secara mendadak yang bisa disebabkan oleh gangguan pernapasan atau henti jantung. Kemajuan teknologi dan farmasi kedokteran di rumah sakit berkembang sangat cepat, tetapi hal ini tidak memengaruhi kelangsungan hidup pasien anak dengan gangguan henti jantung dan paru di rumah sakit. ${ }^{1}$ Dari berbagai jenis kasus, masalah respirasi adalah penyebab tersering dari henti jantung pada anak. ${ }^{2}$

Proses perburukan klinis pada pasien anak dapat dideteksi beberapa jam sebelum terjadinya kondisi serius. Perubahan perilaku dan tanda-tanda gangguan fisiologis sering ditemukan pada anak sebelum mengalami henti napas dan jantung. ${ }^{3} \mathrm{Hal}$ ini dapat digunakan untuk mencegah kejadian henti kardiopulmonal dengan cara mengidentifikasi perburukan klinis dan selanjutnya melakukan tindakan intervensi yang tepat dan cepat. Berdasarkan beberapa penelitian, terdapat dua strategi efektif yang mampu mencegah terjadinya kejadian henti napas dan jantung pada pasien anak, yakni tim gawat darurat dan sistem skor peringatan dini. ${ }^{1}$

Rumah Sakit Cipto Mangunkusumo (RSCM) telah menerapkan pelaksanaan tim gawat darurat dengan adanya tim medis reaksi cepat (TMRC). Setelah diteliti, TMRC dapat memperbaiki tingkat mortalitas pasien di rumah sakit perharinya. ${ }^{1,3}$ Strategi lainnya dalam mendeteksi kondisi gawat darurat anak secara dini di rumah sakit adalah dengan penerapan sistem peringatan dini. Sistem ini menggunakan skorskor tertentu dalam menilai gejala klinis dan dapat memperbaiki pengelolaan perawatan anak dengan kasus akut secara komprehensif. Sistem skoring nursing early warning scoring system (NEWSS) sudah digunakan di RSCM dalam mendeteksi kegawatdaruratan pada pasien. Sistem ini mengevaluasi tanda-tanda vital disertai dengan algoritme yang berfokus pada deteksi kondisi gawat darurat sebelum hal tersebut terjadi. ${ }^{4}$ Dalam mendeteksi perburukan klinis pasien, NEWSS dapat digunakan untuk segala rentang usia. ${ }^{4}$ Penelitian terbaru telah mengembangkan sistem skoring baru dengan tujuan yang sama, tetapi digunakan khusus untuk pasien bayi dan anak, yaitu pediatric early warning score (PEWS). ${ }^{5}$ Sistem PEWS menilai tiga komponen utama, yaitu perilaku, status kardiovaskular, dan status respirasi. Sistem ini juga disertai dengan algoritma sebagai respons terhadap hasil penilaian akhir. ${ }^{3,6}$ Pengukuran tekanan darah, frekuensi nadi, dan penggunaan terapi oksigen adalah perbedaan struktur penilaian pada sistem PEWS dan NEWSS. ${ }^{6}$ Penelitian terhadap sistem PEWS ini belum terlalu banyak ditemukan di Indonesia. Walaupun demikian, sistem skor ini sudah banyak diterapkan di berbagai rumah sakit dunia. Penelitian ini bertujuan untuk mengetahui bagaimana perbandingan antara PEWS dan NEWSS dalam mengidentifikasi deterioriasi klinis untuk mencegah terjadinya kejadian henti napas jantung pada pasien anak di rumah sakit sehingga PEWS dapat digunakan sebagai alternatif pengganti NEWSS.

\section{Metode}

Penelitian ini adalah penelitian uji diagnostik pada pasien anak yang dirawat di IGD RSCM dengan desain potong lintang sejak bulan November 2019 hingga Januari 2020. Kriteria inklusi subjek penelitian adalah anak usia 0-18 tahun yang baru datang atau sedang dalam pemantauan di IGD dengan skor NEWSS 4. Kriteria ekslusi penelitian adalah pasien anak dengan gangguan psikiatri, penyakit jantung bawaan tipe sianotik, penyakit paru kronik, dan pasien anak paliatif (fase end of life). Sampel diambil dengan cara consecutive sampling.

Data pada masing-masing uji dianalisis mengunakan SPSS 20.0. Komponen statistik yang akan dihitung untuk uji PEWS dan NEWSS adalah sensitivitas, spesifitas, positive predictive value (PPV), negative predictive value (NPV), dan area under receiver operator curve (AUROC). Kemudian keduanya akan dibandingkan dan akan diperoleh sistem skor yang lebih baik secara statistik. Uji kesesuaian PEWS dilakukan menggunakan uji kappa.

\section{Hasil}

Nilai uji kappa pada awal penelitian adala 0,83 $(\mathrm{p}<0,001)$. Hal ini menunjukkan bahwa PEWS dapat diandalkan dan digunakan. Selanjutnya, penelitian dilakukan pada 81 anak di IGD RSCM dengan NEWSS Ditemukan 51 subyek (63\%) mengalami perburukan klinis.

Subyek penelitian yang berpartisipasi terdiri dari 47 anak laki-laki (58\%) dan 34 anak perempuan (42\%), dengan kelompok usia terbanyak, yaitu rentang 1-3 tahun (27\%). Kasus infeksi ditemukan lebih 
Rismala Dewi dkk: Perbandingan PEWS dan NEWSS dalam mengidentifikasi deteriorasi klinis pasien anak

Tabel 1. Karakteristik subyek penelitian

\begin{tabular}{|c|c|}
\hline Variabel & $\mathrm{N}=81$ \\
\hline \multicolumn{2}{|l|}{ Usia, n (\%) } \\
\hline $0-12$ bulan & $18(22)$ \\
\hline $1-3$ tahun & $22(27)$ \\
\hline 4-6 tahun & $10(12,3)$ \\
\hline 7-12 tahun & $18(22)$ \\
\hline 13-18 tahun & $13(16)$ \\
\hline \multicolumn{2}{|l|}{ Jenis kelamin, $\mathrm{n}(\%)$} \\
\hline Pria & $47(58)$ \\
\hline Perempuan & $34(42)$ \\
\hline \multicolumn{2}{|c|}{$\begin{array}{l}\text { Diagnosis berdasarkan status infeksi, } \\
\mathrm{n}(\%)\end{array}$} \\
\hline Infeksi & $43(53,1)$ \\
\hline Non-infeksi & $38(46,9)$ \\
\hline \multicolumn{2}{|c|}{$\begin{array}{l}\text { Diagnosis berdasarkan kasus penyakit, } \\
\mathrm{n}(\%)\end{array}$} \\
\hline Hemato-onkologi & $18(22)$ \\
\hline Respirologi & $25(31)$ \\
\hline Neurologi & $8(10)$ \\
\hline Endokrin & $3(3)$ \\
\hline Bedah & $8(10)$ \\
\hline Kardiologi & $1(1)$ \\
\hline Gastrohepatologi & $8(10)$ \\
\hline Nefrologi & $4(5)$ \\
\hline Alergi-imunologi & $5(6)$ \\
\hline \multicolumn{2}{|l|}{ Perburukan, n (\%) } \\
\hline Ya & $51(63)$ \\
\hline Tidak & $30(37)$ \\
\hline \multicolumn{2}{|c|}{ Luaran klinis perburukan, $\mathrm{n}(\%)$} \\
\hline Rawat PICU & $31(38,3)$ \\
\hline Intubasi & $14(17,3)$ \\
\hline Resusitasi jantung paru & $2(2,5)$ \\
\hline Meninggal & $4(4,9)$ \\
\hline \multicolumn{2}{|l|}{ Skor NEWSS (\%) } \\
\hline 4 & $50(61,7)$ \\
\hline 5 & $12(14,8)$ \\
\hline 6 & $6(7,4)$ \\
\hline 7 & $6(7,4)$ \\
\hline 8 & $7(8,6)$ \\
\hline \multicolumn{2}{|l|}{ Skor PEWS (\%) } \\
\hline 4 & $38(46,9)$ \\
\hline 5 & $17(20,9)$ \\
\hline 6 & $11(13,5)$ \\
\hline 7 & $4(4,9)$ \\
\hline 8 & $10(12,3)$ \\
\hline 9 & $1(1,2)$ \\
\hline
\end{tabular}

Tabel 2. Sensitivitas dan spesifisitas PEWS dan NEWS

\begin{tabular}{cccc}
\multicolumn{4}{l}{ dengan luaran deteriorasi klinis } \\
\hline Skor & Sensitivitas & Spesifisitas & p value \\
\hline PEWS & & & $<0,001$ \\
4 & $100 \%$ & $0 \%$ & \\
5 & $80,4 \%$ & $93,3 \%$ & \\
6 & $49,0 \%$ & 96,7 & \\
7 & $29,0 \%$ & $100 \%$ & \\
8 & $21,6 \%$ & $100 \%$ & \\
9 & $2 \%$ & $100 \%$ & \\
NEWSS & & & $<0,001$ \\
4 & $100 \%$ & $0 \%$ & \\
5 & $58,8 \%$ & $96,7 \%$ & \\
6 & $35,3 \%$ & $96,7 \%$ & \\
7 & $25,5 \%$ & $100 \%$ & \\
8 & $13,7 \%$ & $100 \%$ & \\
9 & $0 \%$ & $100 \%$ & \\
\hline
\end{tabular}

banyak jumlahnya dibandingkan dengan kasus noninfeksi. Pasien berhasil diikuti dan diobservasi hingga terjadi deteriorasi klinis atau maksimal 6 jam waktu pengamatan. Subyek yang mengalami perburukan klinis berjumlah 51 anak, terdiri dari $31 \quad(38,3 \%)$ memerlukan perawatan intensif ke PICU atau tetap di zona merah, serta diikuti intubasi 14 (17,3\%), resusitasi jantung paru $2(2,5 \%)$, dan meninggal 4 anak (4,9\%).

Hasil uji statistik pada PEWS didapatkan area under curve (AUC) 87,6\% (95\% CI 0,80-0,95) dengan nilai cut-off sebesar 5. Pada skor tersebut, nilai sensitivitas dan spesifitasnya cukup baik, yakni 80,4\% dan 93,3\%. Selain itu, nilai PPV dan NPV pada PEWS, yakni 95,3\% dan 73,6\%

Pada sistem skor NEWSS didapatkan AUC sebesar $77,8 \%(95 \%$ CI 0,66-0,88) dengan nilai cut-off yang serupa, yakni sebesar 5. Skor NEWSS memiliki spesifisitas yang baik $96,7 \%$, tetapi sensitivitas yang rendah (58.8\%). Didapatkan PPV dan NPV pada NEWSS, yakni 96,7\% dan 58\%.

\section{Pembahasan}

Untuk melihat kesesuaian dari skor PEWS, uji kappa dilakukan guna melihat konsistensi dan reliabilitas alat ketika digunakan berulang. Sejumlah 10 anak diobservasi oleh 2 perawat zona merah IGD RSCM dalam waktu yang bersamaan dan didapatkan hasil skor 
PEWS memiliki nilai kappa 0,83 dan $\mathrm{p}>0,001$. Nilai kappa $>0,6$ pada suatu sistem uji dikatakan memiliki keeratan kesepakatan yang kuat. Hal ini menunjukkan bahwa PEWS cukup andal dan konsisten dapat digunakan di RSCM. Hasil ini sesuai dengan penelitian lain bahwa PEWS bersifat reliabel di Midwestern $($ kappa $=0,92 ; \mathrm{p}<0,001)$ dan Ohio (kappa $=0,91$; $\mathrm{p}<0,001) .{ }^{1,7}$

Penelitian ini dilakukan pada 81 anak dengan rentang usia yang bervariasi, mulai dari usia 1 bulan sampai 17 tahun. Kelompok terbanyak ditemukan pada kelompok usia 1-3 tahun (toddlers), serta jenis kelamin laki-laki memiliki jumlah 1,4 kali lebih banyak dibandingkan perempuan. Penelitian lain mengemukakan hal yang sama bahwa rentang usia toddlers dan jenis kelamin laki-laki merupakan kelompok yang lebih banyak dirawat dirumah sakit. ${ }^{8,9}$ Penelitian Akre $\mathrm{dkk}^{11}$ yang menyatakan bahwa anak laki-laki cenderung lebih aktif bergerak sehingga memiliki risiko lebih tinggi mengalami kecelakan atau cedera, begitu pula dengan risiko akan paparan mikroorganisme yang lebih tinggi dapat menyebabkan penyakit infeksi.

Dari total kasus pasien anak yang datang ke IGD RSCM, 53,1\% merupakan kasus infeksi dan 46,9\% merupakan kasus non-infeksi. Selanjutnya juga ditemukan bahwa gangguan respirasi (31\%) menjadi penyebab terbanyak kasus. Penelitian oleh Nielsen ${ }^{12}$ di tahun 2013 menemukan bahwa penyakit infeksi (60\%) lebih banyak ditemukan pada anak yang dirawat dirumah sakit dibanding dengan penyakit lainnya. ${ }^{11}$ Kemudian, penelitian di Texas tahun 2009 menyebutkan secara spesifik bahwa masalah respirasi merupakan kasus terbanyak penyebab pasien anak datang ke rumah sakit. ${ }^{1}$

Selain itu, pada penelitian di Tiongkok pada tahun 2006-2016 didapatkan penyebab paling umum dari kematian pada anak yang dirawat di rumah sakit adalah pneumonia $(36,7 \%)$, sepsis $(13,5 \%)$, dan tumor $(11,4 \%)$, diikuti oleh perdarahan intrakranial atau gastrointestinal non-traumatis $(10,6 \%)$, syok kardiogenik (9,6\%), infeksi sistem saraf pusat $(7,6 \%)$, kecelakaan $(6,1 \%)$, dan diare $(3,1 \%) .{ }^{12} \mathrm{Hal}$ ini juga sesuai dengan data WHO yang menyebutkan bahwa pneumonia adalah penyebab kematian utama pada balita di dunia. ${ }^{13}$ Laporan Rutin Subdit ISPA pada tahun 2017 juga mendata insiden pneumonia sebesar 20,54 (per 1000 balita) dengan angka mortalitas $0,34 \% .{ }^{14}$
Deteriorasi klinis ditemukan sebanyak 51 anak (63\%) pada penelitian ini. Dari jumlah ini, kasus terbanyak berakhir dengan perawatan intensif ke PICU $(38,3 \%)$, diikuti dengan intubasi $(17,3 \%)$, resusitasi jantung paru (2,5\%), dan meninggal (4\%). Penurunan kondisi klinis yang diikuti henti jantung dan paru memang hanya sedikit jumlahnya $(0,7-3,0 \%)$, tetapi hanya $15-35 \%$ yang bisa bertahan hidup di rumah sakit. ${ }^{15}$

Nilai PEWS memiliki hubungan yang erat dengan kejadi perburukan klinis pasien anak. Skor PEWS yang tinggi akan meningkatkan risiko pasien anak untuk dirawat di ruang intensif. Nilai PEWS terendah adalah 4 (38 anak) dan nilai tertinggi adalah 9 ( 1 anak). Seluruh pasien anak dengan skor PEWS mengalami deteriorasi klinis, sedangkan pasien dengan skor PEWS 4hanya 26\% yang mengalami perburukan klinis. Hasil penelitian Tucker $\mathrm{dkk}^{1}$ menunjukkan bahwa kurang dari $1 \%$ pasien anak memiliki skor PEWS 0-2 yang dipindahkan ke PICU dibandingkan dengan anak yang memiliki skor 9, yaitu sejumlah $80 \%$ dipindahkan rawat ke PICU. Setiap kenaikan PEWS 1 poin memiliki risiko 2 kali lebih besar untuk pasien anak dirujuk ke PICU . ${ }^{1}$ Penelitian pada 2074 pasien anak juga menyebutkan jika anak dengan dengan skor PEWS memiliki kecenderungan untuk dirawat di ruang intensif. ${ }^{16}$ Dari total responden, didapatkan 28 pasien memiliki skor dan seluruhnya dirujuk ke PICU dan NICU. ${ }^{16}$

Tanda vital merupakan status fisiologis yang sangat berperan untuk menentuk status kesehatan individual, terutama pada pasien dengan kondisi medis tidak stabil atau memiliki risiko komplikasi paru dan jantung. Hasil interpretasi dari penilaian tanda vital juga sangat penting dalam menentukan tindakan intervensi selanjutnya. ${ }^{17}$ Baik skor NEWSS dan PEWS memiliki parameter yang bersifat gradual, nilai yang semakin tinggi akan menunjukkan semakin berat derajat perburukan pasien.

Studi statistik pada penelitian ini juga menilai seberapa jauh kemampuan PEWS dalam mengidentifikasi deterioriasi klinik pada pasien anak. Suatu uji akan dikategorikan sebagai uji yang baik jika nilai sensitivitas dan spesifisitasnya mendekati baku emas $(100 \%)$. Pada penelitian ini didapatkan angka sensitivitas $(80,4 \%)$ dan spesifisitas $(93,3 \%)$ yang baik. Diikuti oleh nilai PPV dan NPV, yakni 95,3\% dan $73,68 \%$. Hal ini dapat diartikan bahwa skor PEWS memiliki kemampuan yang baik untuk memprediksi 
apakah seorang anak yang masuk ke rumah sakit akan mengalami deteriorasi klinis atau tidak. Pernyataan ini didukung oleh penelitian yang dilakukan Parshuram $\mathrm{dkk}^{17}$ yang menyatakan bahwa PEWS memiliki sensitivitas (82\%) dan spesifisitas (93\%) yang cukup baik dalam mengidentifikasi perburukan klinik pasien di bangsal yang membutuhkan rujukan ke PICU. ${ }^{16}$

Baik sistem skor PEWS dan NEWSS keduanya dibuktikan dapat memprediksi kejadian deterioriasi klinis pada anak. Di dalam penelitian Tucker dkk, ${ }^{1}$ PEWS juga dapat diandalkan dalam menentukan kondisi anak dan menentukan apakah seorang pasien anak membutuhkan rawatan lanjutan ke ICU atau tidak. ${ }^{1}$ Selain itu, Gold $\mathrm{dkk}^{7}$ juga memperoleh hasil penelitian yang sama.

Berdasarkan hasil AUC dari sistem PEWS dan NEWSS, terlihat bahwa skor PEWS memiliki AUC yang lebih luas dibandingkan dengan NEWS . Dalam mengidentifikasi kejadian perburukan klinis pada pasien anak, PEWS memiliki sensitivitas yang lebih baik dibandingkan dengan NEWSS. Hal ini dapat disebabkan oleh kemampuan PEWS dalam mengevaluasi kebutuhan dan pemberian terapi suplementasi oksigen. Skor PEWS akan semakin tinggi apabila kebutuhan oksigen pasien semakin besar. Penggunaan terapi oksigen dan penilaian sistem pernapasan merupakan indikator fisiologis penting pada pasien anak dengan kondisi kritis., ${ }^{3,18}$ Pada contoh kasus gangguan respirasi akut, seperti pneumonia virus atau bakteri akut yang berat, bisa berakhir dengan kondisi gagal napas dan salah satu manajemennya berupa pemberian terapi oksigen 4-6L/menit untuk mencapai $\mathrm{PaO}_{2}$ di atas $60 \mathrm{mmHg}$. Dari gambaran ini, bisa disimpulkan bahwa derajat keparahan penyakit dapat di prediksi dari seberapa banyak kebutuhan oksigen pasien.?

Selanjutnya, skor PEWS dan NEWSS memiliki spesifitas yang sama baik dalam menilai perburukan klinis pasien anak. Skor NEWSS memiliki spesifitas yang lebih unggul disebabkan oleh penilaian komponen penilaian tekanan darah dan cut-off denyut nadi yang lebih kecil, yaitu $>10$ kali per menit di atas normal. Penilaian kondisi klinis oleh NEWSS pada pasien kritis menjadi lebih spesifik dibandingkan dengan skor PEWSS yang tidak memiliki komponen tekanan darah dan cut-off nadi yang lebih tinggi, yaitu $>20$ kali per menit di atas normal. Akan tetapi, parameter tekanan darah tidak sesuai dalam mengidentifikasi kondisi kritis pada anak, terutama kasus syok. Penurunan tekanan darah atau hipotensi adalah gejala akhir yang terjadi setelah tanda-tanda lain (takikardia, denyut nadi melemah, bradikardia dan pengisian kapiler lambat). Selain itu, prosedur pengukuran tekanan darah anak lebih sulit dibandingkan pasien dewasa. Hasil tekanan darah dapat dipengaruhi oleh perilaku anak (mengangis atau banyak bergerak), ukuran manset yang tidak sesuai, dan nilai normal tekanan darah untuk masing-masing rentang usia berbeda dan jarang ditampilkan dirumah sakit. ${ }^{19}$

Penelitian lain telah dilakukan untuk menguji skor PEWS pada pasien anak di rumah sakit. Penelitian tersebut menguji 2979 anak secara retrospektif dengan rekam medis selama periode 1 tahun. ${ }^{1}$ Bila dibandingkan dengan penelitian tersebut, penelitian ini memiliki keunggulan karena dilakukan secara prospektif karena pasien anak yang dirawat diobservasi selama 6 jam hingga terjadi deteriorasi klinis. Namun demikian, kelemahan penelitian ini adalah subyek penelitian hanya diambil dari pasien yang masuk ke IGD dengan skor NEWSS dengan pertimbangan pasien di bangsal perawatan serta pasien dengan skor 0-3 memiliki risiko rendah akan terjadinya perburukan klinis.

\section{Kesimpulan}

Skor PEWS lebih baik dibandingkan dengan skor NEWSS dalam menilai deteriorasi klinis pada pasien anak yang dirawat di rumah sakit. Hasil penilaian skor PEWS juga dapat digunakan sebagai acuan akan tindakan intervensi lanjutan pada pasien anak. Semakin tinggi skor total PEWS akan semakin tinggi pula risiko perburukan klinis yang mencermikan kondisi kritis pasien.

\section{Daftar pustaka}

1. Tucker KM, Brewer TL, Baker RB, Demeritt B, Vossmeyer MT. Prospective evaluation of a pediatric inpatient early warning scoring system. JSON 2009; 14:78-75.

2. Young KD, Seidel JS. Pediatric cardiopulmonary resuscitation: a collective review. Ann Emerg Med 1999;33:195-205.

3. Dewi R. Pediatric early warning score: Bagaimana langkah kita selanjutnya?. Sari Pediatri 2016;18:68-73.

4. Firmansyah H. Peran perawat dalam penanganan kegawatan klinik di rumah sakit. 2009 [diakses tanggal 13 Juli 2018]. 
Didapat dari: http://www.academia.edu/nursing_early_ warning_scoring_system.

5. Duncan H, Hutchison J, Parshuram CS. Pediatric early warning system score: a severity of illness score to predict urgent medical need in hospitalized children. J Crit Care 2006;21:271-9.

6. Monaghan, A. Detecting and managing deterioration in children. J Paeditr Nurs2005;17:32-35.

7. Gold DL, Leslie KM, Daniel MC. Evaluating the pediatric early warning score (PEWS) system for admitted patients in the pediatric emergency department. Acad Emerg Med 2014;21:1249-56.

8. Wahyudi P, Indriati G, Bayhakki. Gambaran skor pediatric early warning score pada pola rujukan pasien anak di instalasi gawat darurat. J PSIK 2014;1:1-8.

9. Fenix JB, Gillespie GW, Levin A, Dean N. Comparison of pediatric early warning score to physician opinion for deteriorating patients. J Pediatr 2015;5;474-9.

10. Akre M, Finkelstein M, Erickson M, Liu M, Vanderbilt L, Billman G. Sensitivity of the pediatric early warning score to identify patient deterioration. J Pediatr2010;125:763-9.

11. Nielsen KR, Migita R, Batra M, Gennaro JLD, Roberts JS, Weiss NS. Identifying high-risk children in the emergency department. J Intensive Care Med 2016;31:660-6.

12. Zhang M. Causes of death in hospitalized children younger than 12 years of age in a Chinese hospital: a 10 year study. BMC Pediatr 2018;2:18-24.

13. World Health Organization. Pediatric emergency triage, assessment and treatment: care of critically-ill children. 2016. Diakses pada 12 April 2020. Didapat dari: https:// apps.who.int.

14. Kementerian Kesehatan RI. Profil kesehatan Indonesia tahun 2017. Jakarta: Kementerian Kesehatan Republik Indonesia; 2018.

15. Nadkarni V, Larkin G, Peberdy M, Carey S, Kaye W, Mancini M, dkk. First documented rhytm and clinical outcome from hospital cardiac arrest among children and adults. J Ame Med Assoc 2006;1:50-7.

16. Parshuram CS, Duncan HP, Joffe AR, Farrell CA, Lacroix JR, Middaugh KL dkk. Multicentre validation of the bedside paediatric early warning system score: a severity of illness score to detect evolving critical illness in hospitalised children. Pediatr Crit Care Med 2011;15:1-10.

17. Elliott M, Coventry A. Critical care: the eight vital signs of patient monitoring. Brit J Nurs 2012;10-621-5.

18. Solevag A, Eggen E, Schroder J, Nakstad B. Use of a modified pediatric early warning score in a department of pediatric and adolescent medicine. PLoS One 2013;8:723-4.

19. Bird C. Measuring blood pressure in children. BMJ 2008;14:135-39. 